\title{
Spine Cancer pT2 TNM Finding v8
}

National Cancer Institute

\section{Source}

National Cancer Institute. Spine Cancer pT2 TNM Finding v8. NCI Thesaurus. Code

C136586.

Spine cancer with tumor confined to three adjacent vertebral segments. (from AJCC 8th Ed.) 